\title{
アルミニウム合金板材の面外曲げ疲労強度に及ぼす曲げ加工の影響十
}

\author{
大 川 慶 ${ }^{*}$ 工 藤 充 史 ${ }^{* *}$ \\ 安藤丈 裕** 大川功***

\section{Effect of Bending-Work on Fatigue Strength of Aluminum Alloy Plate under Out-of-Plane Bending}

\author{
by \\ Kei OhKawa ${ }^{*}$, Atsushi Kudo ${ }^{* *}$, Takehiro Ando ${ }^{* *}$ and Isao OHKawa ${ }^{* * *}$
}

Fatigue tests were performed on $90^{\circ} \mathrm{V}$-shape bending-worked aluminum alloy specimens with various radii of curvature under deflection-controlled fully-reversed out-of-plane bending to clarify the effect of bending-work on fatigue strength of plates. Fatigue strength of the bent specimens was entirely lower than that of smooth flat one and decreased with reduction in radius of curvature. In order to investigate the cause of the reduction in fatigue strength of bent specimens, stress state in the vicinity of the bending-worked portion was analyzed employing a finite element method. Besides, crack initiation and growth behavior was observed and compared with those of smooth flat specimen. The crack initiation tends to be earlier with decreasing the radius of curvature because of the higher stress concentration around the center of inner surface of the bent portion. In addition, the crack growth rate in bent specimens was higher than that in flat specimen, especially in an early stage of short crack growth regime and increased with decreasing the radius of curvature. Since cyclic bending stress decreased with crack growth and accumulation of residual strains, the crack growth rate gradually lowered in latter stage of the life. Consequently, the reduction of fatigue strength in bending worked plate results from the earlier crack initiation and the acceleration of crack growth rate in early stage due to the stress concentration around the bent portion.

Key words : Fatigue strength, Bending-work, Out-of-Plane bending, Aluminum alloy, Crack growth, Stress concentration

\section{1 緒 論}

実機には曲げ加工により成型された板材部品が多く用 いられており，これらが繰返し負荷を受けて疲労破壊す る事例が報告されているが，この曲げ加工が板材の疲労 強度に及ぼす影響について検討した研究事例は極めて少 ない.1)，2このような曲げ加工材の疲労強度に関する知見 は, 多数の曲げ加工成型部材により構成される実機の疲 労設計に役立つだけでなく, 曲げ加工法の改善や他の疲 労破壊防止策について検討するためにも必要不可欠なも のである.

本研究では, 種々の曲率半径を有するアルミニウム合 金の $90^{\circ}$ 曲げ加工板材を用いて両振り面外曲げ疲労試験 を行い，この曲げ加工が板材の疲労強度に及ぼす影響に ついて調べた.3)〜5)さらに, 曲面状に加工された曲げ部内 側表面から発生, 成長する疲労き裂の進展挙動を観察す るとともに, 繰返しにともなう曲げモーメントやひずみ の変化を測定した。 得られた試験結果を平板平滑試験片 のそれと比較することにより，曲げ加工が板材の面外曲 げ疲労強度に及ぼす影響について詳細に検討した。

\section{2 試料および試験方法}

\section{$2 \cdot 1$ 供試材および試験片}

供試材は板厚 $3 \mathrm{~mm}$ のアルミニウム合金 A5052P-H34 板材である。引張試験片および疲労試験片は，その長手 方向がいずれも素材の圧延方向と一致するように採取し た. 供試材の化学成分と機械的性質を Table 1 に示す. まず，素材を Fig. 1 (a)に示す形状の平板平滑試験片に 機械加工し，さらにこれを Fig. 1 (b)に示すように，挟 み角が $90^{\circ}$ となるよう曲げ加工した。曲げ加工部内側の 曲率半径は 15,6 および $3 \mathrm{~mm} の 3$ 種類であり以後, こ れらの試験片をそれぞれ，R15，R6，R3 曲げ加工材と表 記する。なお，各試験片の最小断面部の板幅は基本的に

Table 1 Chemical composition and mechanical properties.

\begin{tabular}{|c|c|c|c|c|c|c|c|c|}
\hline Chemical composition & $\mathrm{Si}$ & $\mathrm{Fe}$ & $\mathrm{Cu}$ & $\mathrm{Mn}$ & $\mathrm{Mg}$ & $\mathrm{Cr}$ & $\mathrm{Zn}$ & $\mathrm{Ti}$ \\
\cline { 2 - 8 } wt $\%$ & 0.25 & 0.4 & 0.1 & 0.1 & 2.8 & 0.35 & 0.1 & - \\
\hline \multirow{3}{*}{$\begin{array}{c}\text { Mechanical } \\
\text { propeties }\end{array}$} & \multicolumn{3}{|c|}{ Young's modulus $\mathrm{GPa}$} & \multicolumn{3}{c|}{66.7} \\
\cline { 2 - 7 } & $0.2 \%$ proof stress $\mathrm{MPa}$ & \multicolumn{3}{|c|}{184} \\
\cline { 2 - 7 } & \multicolumn{3}{|c|}{ Tensile strength MPa } & \multicolumn{3}{|c|}{213} \\
\cline { 2 - 7 } & \multicolumn{3}{|c|}{ Elongation \% } & \multicolumn{3}{c}{14} \\
\hline
\end{tabular}

$\dagger$ 原稿受理 平成 24 年 12 月 21 日 Received Dec. 21, 2012 @ 2013 The Society of Materials Science, Japan

* 学生会員 法政大学大学院 ₹ 184-8584 小金井市梶野町, Graduate school, Hosei Univ., Kajino-cho, Koganei, 184-8584

** JUKI (株) ₹ 206-8551 多摩市鶴牧, JUKI corporation, Tsurumaki, Tama, 206-8551

*** 正 会 員 法政大学理工学部 † 184-8584 小金井市梶野町, Faculty of Sci. and Eng., Hosei Univ., Kajino-cho, Koganei, 184-8584 


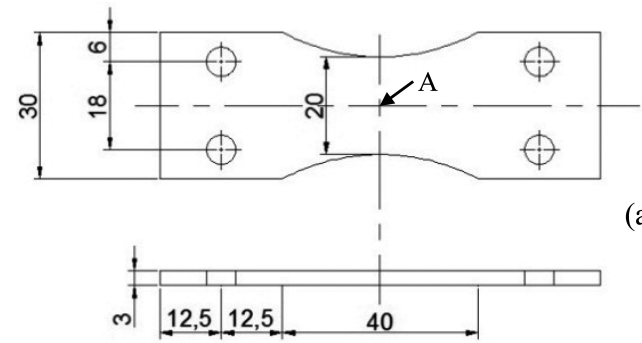

(a) Smooth specimen

(b) Bent specimen $\mathfrak{m}$
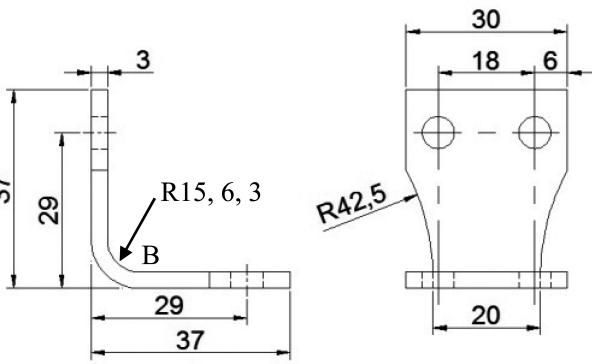

Fig. 1 Configuration of smooth and bending-worked specimens.

はすべて $20 \mathrm{~mm}$ であるが，平滑材の長寿命域での試験で は試験片取付け部でのフレッティングによる破壊を防ぐ ため，板幅を $18 \mathrm{~mm}$ とした試験片も用いた。

曲げ加工は, $90^{\circ}$ 溝下型と $90^{\circ}$ 上型をプレスブレーキ に取付け，平板試験片を冷間において 15 秒間で一回型 曲げを行うこととした。 その際，板外表面の長手方向に おけるひずみ速度は, 内側曲げ半径 $\mathrm{R}=15 \sim 3 \mathrm{~mm}$ に対 して $6 \times 10^{-3} / \mathrm{s} \sim 2 \times 10^{-2} / \mathrm{s}$ 程度である.この曲げ加工 が機械的性質に及ぼす影響を調べるため，試験片を長手 方向に切断し，断面内での長手方向のマイクロビッカー 不硬さの分布を調べた。その結果，曲げ変形の大きい箇 所での硬さは，加工の影響がない部分に比べて $15 \%$ 程度 硬度が高くなっていることがわかった.6)この冷間加工に よる硬化の程度は, 材質, 加工度, 加工方法や加工速度 に依存する。曲げ半径 R が小さくなるほど硬化量は大き くなる傾向がみられたが, これは, 主として試験片長手 方向に生じる最大ひずみが曲げ半径 $\mathrm{R}$ の減少につれて増 大することに起因するものであると考えられる.

\section{$2 \cdot 2$ 疲労試験およびき裂観察}

疲労試験には，曲げ变位一定型の面外曲げ疲労試験機 （東京衝機製造所製，PBF-30C）を用い，繰返し速度は $1000 \mathrm{cpm}$ とした。曲げ加工材を試験機に取り付ける際に は，基準面から試験部の曲げ中心までの距離が平板平滑 材のそれと同一となるように，各曲げ加工材ごとに専用 の固定治具を用いた.

各試験片に両振りの曲げ変位を負荷して面外曲げ疲労 試験を行い, 疲労寿命 $\mathrm{N}_{\mathrm{f}}$ を求めた. 繰返し数が $10^{7}$ 回を 超えても破壊しない場合は打切りデータとし，107 回時 間強度の推定にはステアケース法を用いた。繰返しにと もなう曲げモーメントの変化を測定し， $1 / 2 \mathrm{~N}_{\mathrm{f}}$ の時点で の曲げモーメント $\mathrm{M}$ を用いて, 各試験片の公称曲げ応力 $\sigma_{\text {nom }}$ を次式より算出した.

$$
\sigma_{n o m}=\frac{6 M}{b t^{2}}
$$

ここで $\mathrm{b}$ および $\mathrm{t} は ，$ 試験片の最小断面部の幅と厚さで ある. 寿命試験の結果得られた各材の瘦労強度は, 平板 平滑材の $10^{7}$ 回時間強度 $\sigma_{\mathrm{w} 0}$ により標準化した值, $\sigma / \sigma_{\mathrm{w} 0}$ を用いて表示した。

平滑材，曲げ加工材ともに，一部の試験片では Fig. 1 に示す最小断面中央部 A，Bの表裏に電気抵抗線ひずみ ゲージを貼り，この箇所に生ずるひずみを測定した。疲労 き裂は平滑材では最小断面部の両端で, 曲げ加工材では 加工部内側中央付近で発生し板幅方向に沿って伝ぱする. 所定の繰返し数ごとに試験機を停止し, 静的曲げモーメ ントを負荷してき裂を開口させた状態で表面レプリカを 採取し，光学顕微鏡を用いて観察した。き裂の発生は， 板幅方向に沿って長さ $0.1 \mathrm{~mm}$ のき裂が認められた時点 とした。また，き裂を所定の長さまで成長させた後，試 験部を切断，研磨することにより平滑材と曲げ加工材に おけるき裂面形状とアスペクト比の変化を調べた.

\section{3 実験結果および考察}

\section{$3 \cdot 1$ 疲労強度に及ぼす曲げ加工の影響}

寿命試験の結果より得られた平板平滑材および各曲げ 加工材の S-N 線図を Fig. 2 に示す。縦軸の曲げ応力は, 曲げ加工を受けていない平滑材の疲労限度（107 回時間 強度） $\sigma_{\mathrm{w} 0}$ により標準化して表示した。曲げ加工半径 $\mathrm{R}$ が小さくなるにつれて疲労強度は低下し, S-N 曲線は順 次下方に移動することがわかる。曲げ加工部内側での曲 率半径が最も小さい $\mathrm{R} 3$ 曲げ加工材では, 疲労限度は平 滑材のおよそ $50 \%$ にまで減少する.

この曲げ加工材の疲労強度の低下は, 曲げ加工部に生 ずる応力集中によるものであると考えられる。そこで， 弾性有限要素法 (FEM) により平滑材および曲げ加工材 の最小断面部における応力状態を解析した．加工部表面 では二軸応力状態となっているが，試験片長手方向に沿 う応力の式 (1)の公称曲げ応力に対する比, $\sigma / \sigma_{\text {nom }}$ とし て表示すると，平滑材および曲げ加工材の加工部内側表 面における応力の板幅方向に沿った分布は Fig. 3 のよう になる。平滑材の表面における曲げ応力はほぼ一様であ るが，両端でわずかに大きく，この箇所での弾性応力集 中係数 $\mathrm{K}_{\mathrm{t}}$ は 1.038 である. 曲げ加工材では最大曲げ応力

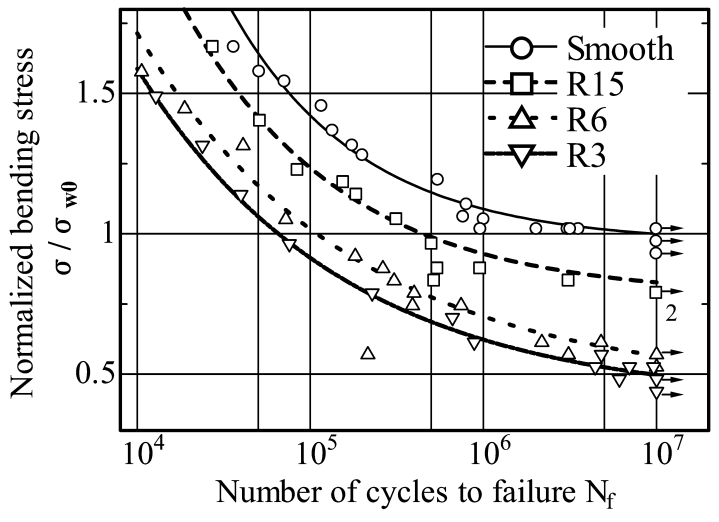

Fig. 2 S-N diagrams. 


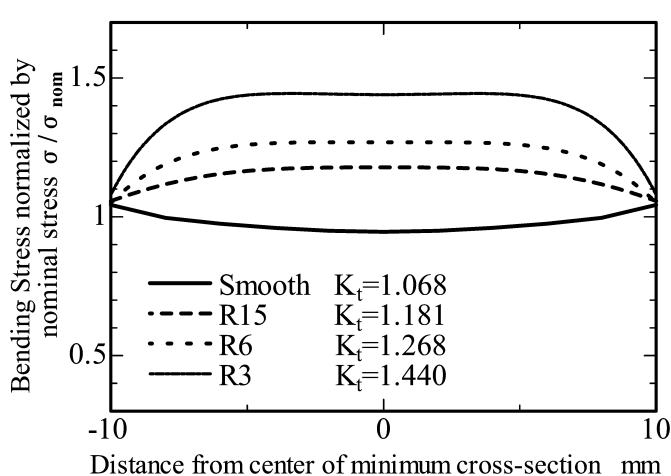

Fig. 3 Variation of bending stress at inner surface.

は加工部内側表面の中央部分にて生じる，R15 材，R6 材 および R3 材における弾性応力集中係数 $\mathrm{K}_{\mathrm{t}}$ はそれぞれ， 1.181，1.268 および 1.440 であり，曲率半径が減少する と $\mathrm{K}_{\mathrm{t}}$ は急増する傾向を示す.

Fig. 4 は曲げ加工部の内側および外側表面中央におい て, 多段振幅変動法により測定した繰返し曲げ応力ーひ ずみ関係を示したものである。曲げ加工部の曲率半径を 増す方向のモーメントが作用した場合を想定して，加工 部内側および外側面に生ずるひずみをそれぞれ，引張側 と圧縮側にプロットした。応力は平滑材の疲労限度 $\sigma_{\mathrm{w} 0}$ により標準化した值を用いて表示した。曲げ加工材の加 工部外側でのひずみは平滑材よりもやや小さいが，内側 でのひずみは曲率半径 $\mathrm{R}$ が小さくなるにつれて増加し， 応力集中が顕著となる。

Fig. 4 の弾性範囲でのひずみの測定值より求めた応力 集中係数と曲げ加工部の内側曲率 $1 / \mathrm{R}$ の関係を Fig. 5 に示す。前述の弾性 FEM と曲がりはりの理論 7)より得 た曲線も合わせて示す。内側および外側表面での応力集 中係数は,いずれも弾性 FEM のほうが大きく評価される が，この結果はひずみ測定から得られた実測值に近い。

\section{$3 \cdot 2$ 疲労き裂の発生}

前述のように, 曲げ加工部内側表面には応力が集中す るが，この箇所に生じた最大応力を平滑材の寿命曲線に 適用して曲げ加工材の疲労寿命を求めてみると，とくに 加工部の曲率半径が小さく応力集中が顕著な場合には， 過度に安全側の評価となることがわかった。そこで，局 所的な応力集中の影響のみならず，この応力集中部付近 から発生, 伝ぱするき裂の観察を行い, 疲労き裂成長の

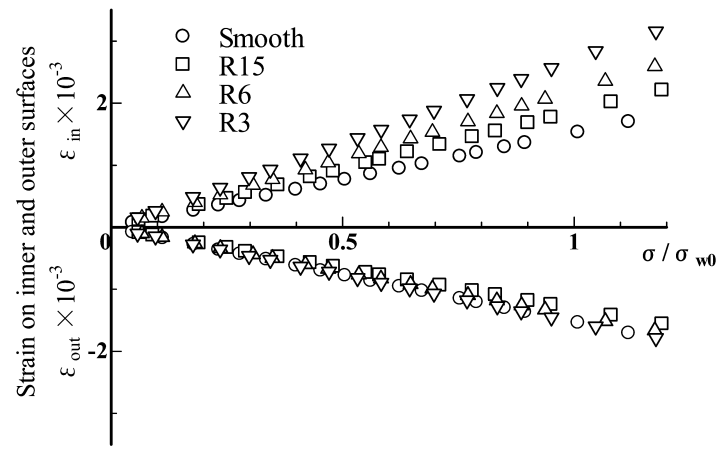

Fig. 4 Strains on inner and outer surfaces of bent specimens.
観点から，疲労強度に及ぼす曲げ加工の影響についてさ らに考察した。

Fig. 3 から明らかなように，平板平滑材では最小断面 部の板幅方向の両端で，また曲げ加工材では加工部内側 中央で曲げ応力は最大となることから, 疲労き裂はいず れもこの近傍で発生，成長した。 Fig. 6 は，各試験片に 同一の曲げ応力 $1.31 \sigma_{\mathrm{w} 0}$ を繰返した場合の疲労き裂の成 長曲線の例である。いずれも板幅方向に沿って多数のき 裂が発生し，7〜10mm 程度の長さにまで進展した後， 急速に合体，伝ぱして破断に至った。破壊に関与した 3 本程度の主き裂を選んで表示しているが，曲率半径 $\mathrm{R}$ が 小さくなるほどき裂の発生時期は早く，き裂成長も促進 されることがわかる.

平滑材の疲労限度 $\sigma_{\mathrm{w} 0}$ の $0.87 \sim 1.57$ 倍の範囲の曲げ 応力を負荷し, 各試験片におけるき裂発生寿命 $\mathrm{N}_{\mathrm{i}}$ を調 べた結果を Fig. 7 に示す。曲げ応力が増加するほど，ま た曲率半径 R が小さくなるほど，き裂発生寿命は短くな ることがわかる。き裂発生は危険箇所における局所的な 弾塑性ひずみに支配されると考え，曲げ加工材の最小断 面内側中央に生じる弾塑性の最大ひずみ $\varepsilon_{\max }$ を, Neuber 則 ${ }^{8)}$
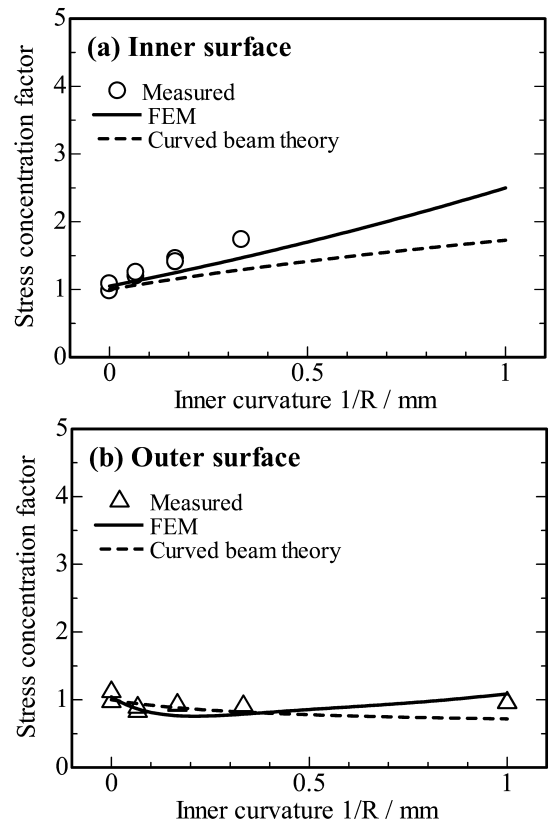

Fig. 5 Stress concentration at inner and outer surfaces.

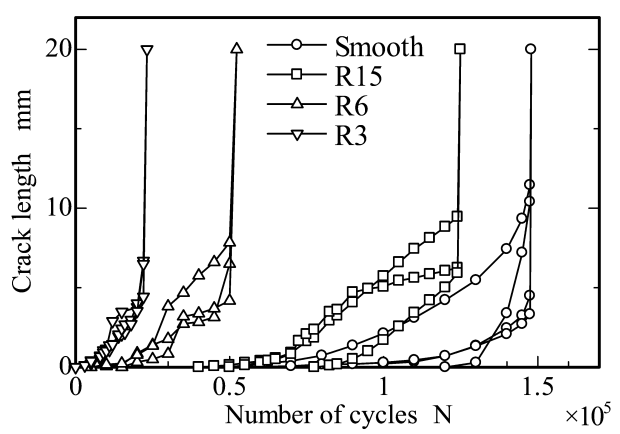

Fig. 6 Crack growth curves. 


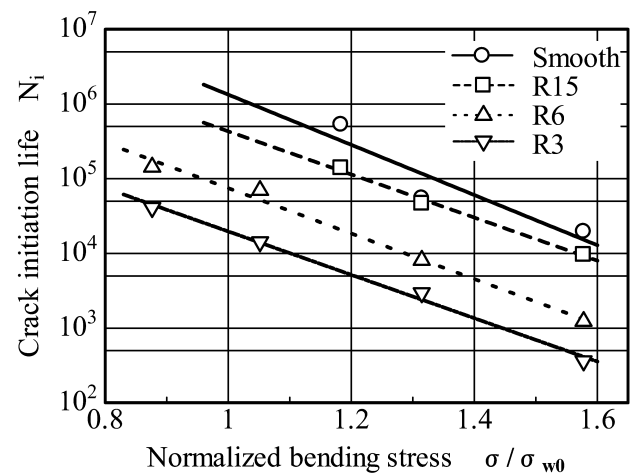

Fig. 7 Number of cycles to crack initiation.

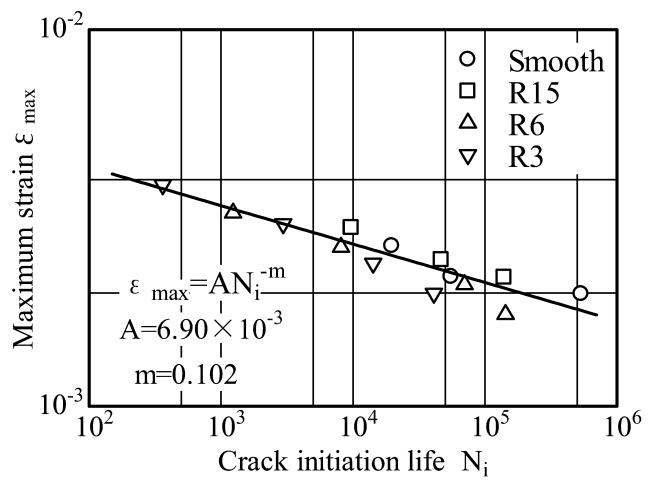

Fig. 8 Relation between maximum strain and crack initiation life.

$$
\mathrm{K}_{t}=\mathrm{K}_{\sigma} \cdot \mathrm{K}_{\varepsilon}
$$

に平板平滑材の繰返し応力ーひずみ関係

$$
\varepsilon=\frac{\sigma}{E}+\left(\frac{\sigma}{\mathrm{k}}\right)^{\frac{1}{n}}
$$

を適用して算出した。ここで， $\mathrm{K}_{\sigma}$ と $\mathrm{K}_{\varepsilon}$ はそれぞれ，弾 塑性応力集中係数と弾塑性ひずみ集中係数であり，弾性 応力集中係数 $\mathrm{K}_{\mathrm{t}}$ には弾性 FEM 解析により求めた值を用 いた。また, 式 (3)中の繰返し強度係数 $\mathrm{k}$ は $448 \mathrm{MPa}$, 繰返し加工硬化指数 $\mathrm{n}$ は 0.0827 である.

このようにして算出した弾塑性の最大ひずみ $\varepsilon_{\max }$ を用 いて，各材のき裂発生寿命を整理したものが Fig. 8 であ る. 試験片の種別によらず，各材のき裂の発生寿命は両 対数線図上の直線の近傍にプロットされることから，こ れよりき裂発生寿命を求めることができる.

\section{$3 \cdot 3$ 疲労き裂の成長挙動}

各試験片の応力集中部付近で発生したき裂のうち, 直 接破壊に関与した 3 本程度の主き裂を選び，それらのき 裂成長過程を観察した。平板平滑材の場合は最小断面部 の四隅から発生した表面き裂長さ c の, また曲げ加工材 では中央部から発生した表面き裂全長 $2 \mathrm{c}$ の変化を測定 し, 増分多項式法によりき裂成長速度 $\mathrm{dc} / \mathrm{dN}$ を算出し た. 各試験片とも $1.05 \sim 1.57 \sigma_{\mathrm{w} 0}$ の範囲の 3 応力レベル に打いて試験を行い，その結果を長さ $\mathrm{c}$ に対して表示し たものが Fig. 9 である.プロットはかなりばらついてい るが, 各試験片ともき裂成長速度とき裂長さの関係を, 両対数線図上の直線により近似した. Fig. 9 (a)に示す平 滑材の場合は，とくにき裂長さの短い領域でのき裂成長
が遅いが, Fig. 9 (b)〜 (d)の曲げ加工材では, 曲率半径 $\mathrm{R}$ が小さくなるにつれて繰返し初期段階のき裂長さが短 い領域でのき裂成長速度が増大する傾向にある.

Fig. 9 の各試験片のき裂成長速度を, き裂先端におけ る弾塑性ひずみから算出したひずみ拡大係数幅 ${ }^{9)}$ に基づ いて評価することを試みた. Fig. 10 は平板平滑材と R6 曲げ加工材のき裂面形状とアスペクト比を調べた結果を 示したものである．平滑材では 2 つ応力レベルにおい て繰返しにともなう表面き裂長さ $\mathrm{c}$ と端部の深さ a の変 化を測定した。曲げ加工材では，平滑材の疲労限度 $\sigma_{\mathrm{w} 0}$ の $0.87 \sim 1.57$ 倍の範囲の応力を繰返して所定のき裂長

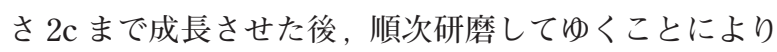
個々のき裂の表面から最深部までの距離 $\mathrm{a}$ を求めた。き 裂前縁形状は平滑材ではほほ $1 / 4$ だ円形, R6 曲げ加工 材では半だ円形であり，いずれの場合もき裂成長にとも なってアスペクト比は減少する。これらの観察結果に基 ゔき，平滑材の場合は $1 / 4$ だ円形の縁き裂に対する応力 拡大係数幅の評価式 $\left.{ }^{10)}, 11\right)$ を, また曲げ加工材の板幅中 央部から伝ぱする半だ円き裂の応力拡大係数幅には, 曲 率半径 Rによらずアスペクト比の変化は同一として, Newman-Rajuの表面き裂に対する解 ${ }^{12)}$ を用いた。さら に, これらの評価式中の応力幅 $\Delta \sigma$ を $3 \cdot 2$ 節で求めた弾 塑性の引張最大ひずみ $\varepsilon_{\max }$ で置換えてひずみ拡大係数幅 $\Delta \mathrm{K}$ を算出し, これに縦弾性係数 $\mathrm{E}$ を乗じたパラメータ $\mathrm{E} \Delta \mathrm{K}$ を用いて，各試験片のき裂成長速度を評価した。

Fig. 9 のき裂長さ $\mathrm{c}=0.1 \sim 9 \mathrm{~mm}$ の範囲において，各 回帰直線上での 9 組の $\{\mathrm{c}, \mathrm{dc} / \mathrm{dN}\}$ の值に対して上記の パラメータ $\mathrm{E} \Delta \mathrm{K}$ を適用した結果を Fig. 11 に示す。また すべての結果を Fig. 12 にまとめて表示した. Fig. 12 で は全試験結果はある幅をもつ領域に収まっているように みえるが，依然として試験片形状や応力レべルによるき 裂成長速度の相違が認められ，便宜的に上記のパラメー タを用いて各材のき裂成長を統一的に評価することは難 しい.

平面曲げの高応力下での長さ $l$ の微小き裂の成長速度 を律するパラメータとして, 繰返し曲げ応力や塑性ひず みのべき乗を用いた $\sigma^{n} l$ あるいは $\varepsilon_{\mathrm{p}}{ }^{n} l$ の有用性が報告さ れている. ${ }^{13)}$ 本研究では, 曲げ加工材の内側表面における 応力集中の影響を考慮した弾塑性の最大曲げ応力 $\sigma_{\max }$ を 式 (2) と(3)より求め, そのべき乗を用いたパラメータ $\sigma_{\max }{ }^{7.3} \mathrm{c}$ によりき裂成長速度を評価した．Fig. 13 に示す ように, 平滑材と曲げ加工材のき裂成長は依然として相 違するものの，曲げ加工材のき裂成長速度は，曲率半径 や応力レベルによらず狭い領域にプロットされるという 結果が得られた。

Fig. 8 の結果を用いてき裂発生までの寿命 $\mathrm{N}_{\mathrm{i}}$ を求め, また Fig. 13 の回帰直線の式を発生時のき裂長さ $\mathrm{c}_{\mathrm{i}}=$ $0.1 \mathrm{~mm}$ から破壊時の長さ $\mathrm{c}_{\mathrm{f}}=10 \mathrm{~mm}$ に至るまで積分し て伝ぱ寿命 $\mathrm{N}_{\mathrm{p}}$ を求め，両者を合算して全寿命 $\mathrm{N}_{\mathrm{f}}$ を試算 した。その結果を Fig. 14 に示す。き裂の発生と伝ぱの 実測值に基づいて計算した寿命であるから当然のことで あるが，予測寿命は実測值とよく一致している. 

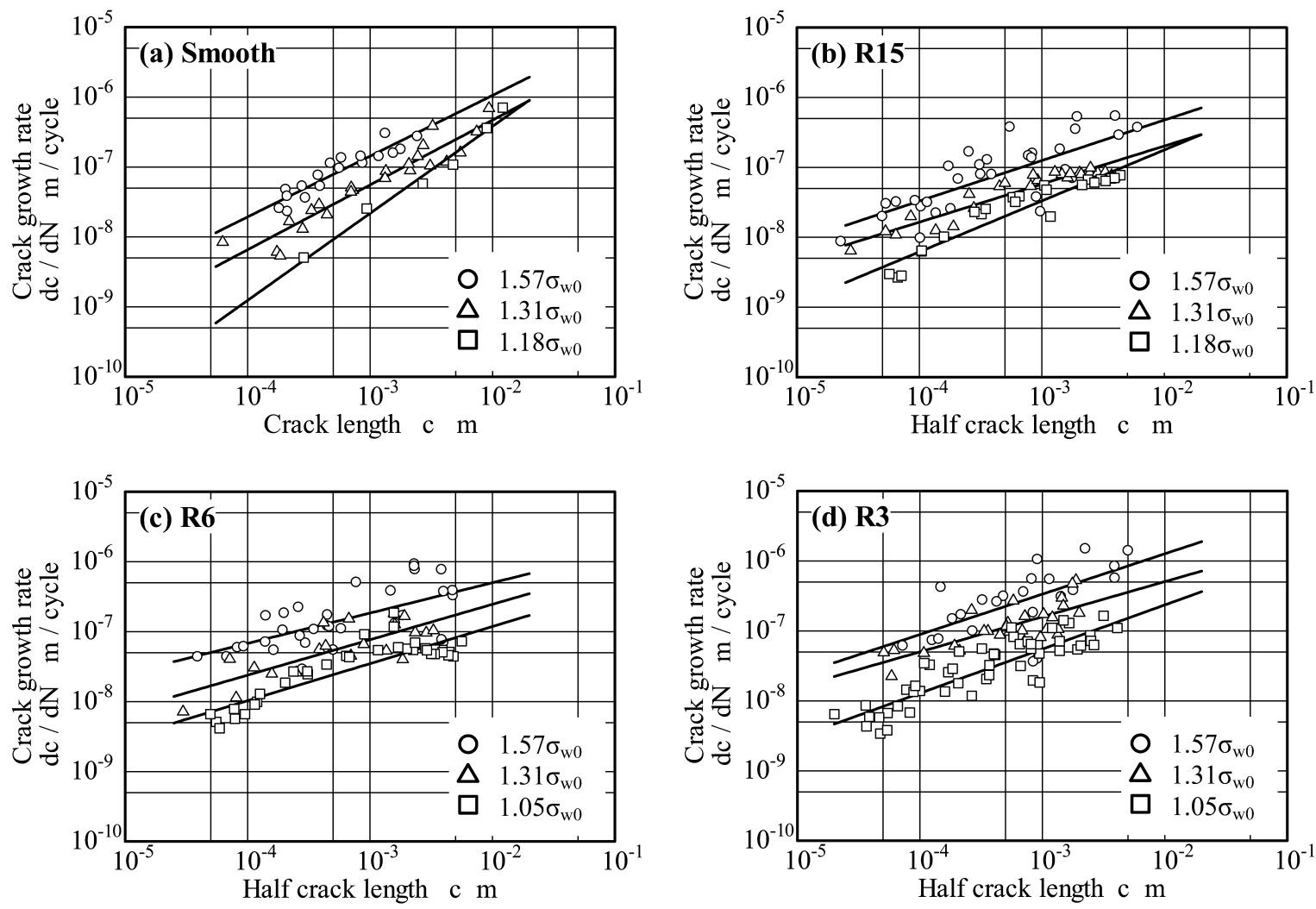

Fig. 9 Comparison of crack growth rate.
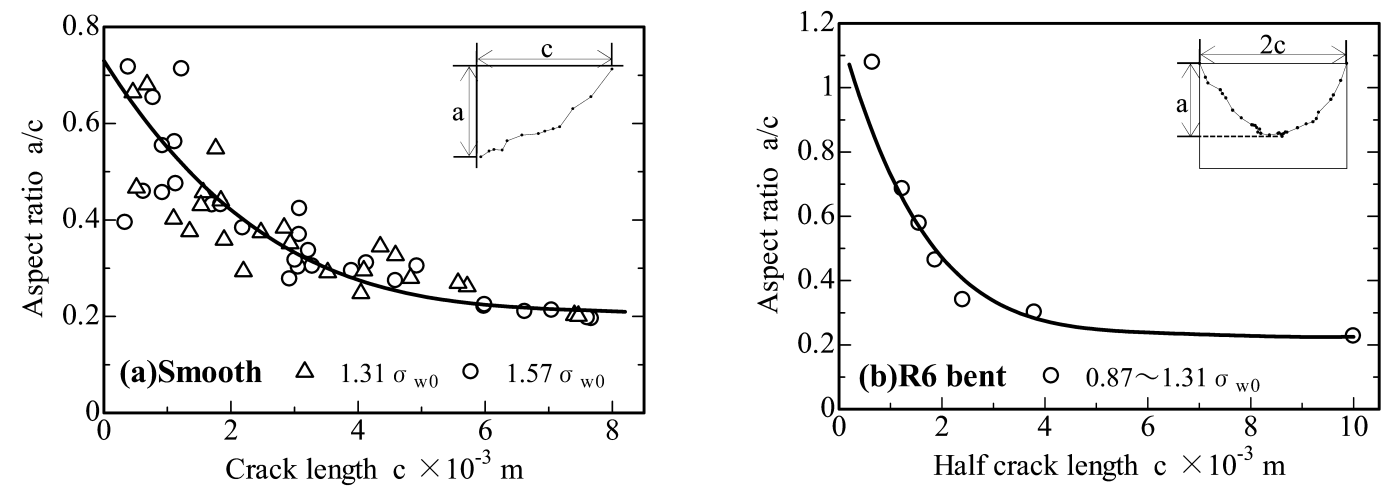

Fig. 10 Relation between aspect ratio and surface crack length in smooth and bent specimens.

板材に冷間加工を施すと加工部に残留応力を生じ，こ の残留応力の影響により寿命は非加工材よりも延伸する ことが報告されている.14), 15)本研究の曲げ加工材におい ても，き裂の発生個所となる加工部内側表面に生じる初 期残留応力や加工硬化 $(2 \cdot 1$ 節参照 $)$ が, 同様な影響 を寿命に及ぼすと考えられる。しかし，このような寿命延 伸効果にもかかわらず，Fig. 2 のように曲げ加工を施す と短寿命になるのは, これに重畳される応力集中の影響の ほうがより大きいことを意味している。このため, Fig. 7 と Fig. 9 に示したように，曲げ加工材では疲労き裂は早 期に発生し，かつき裂長さの短い繰返し初期におけるき 裂成長が促進され，その結果，短寿命になったと考えら れる。なお，き裂長さの長い領域で曲げ加工材のき裂成 長速度が低下する原因については次節で考察する.

\section{$3 \cdot 4$ 繰返しによる曲げモーメントとひずみの変化}

本研究で用いた疲労試験機は曲げ変位一定型であるた め, 繰返し過程での硬化/軟化や疲労き裂の成長にとも なって曲げモーメントは変化する. Fig. 15 は, 平滑材と 曲げ加工材の寿命がいずれも $10^{5}$ 回程度となるような曲 げ変位を負荷した場合の繰返しにともなう最大および最 小曲げモーメント， $\mathrm{M}_{\max }$ と $\mathrm{M}_{\min }$ の変化を示したもので あり，曲げ半径 $\mathrm{R}$ を減ずる方向に作用するモーメントを 正として表示している。平滑材では最大值 $\mathrm{M}_{\max }$ と最小 值 $\mathrm{M}_{\min }$ の大きさはともに寿命終期に減少する。これに 対し, 曲げ加工材では $\mathrm{M}_{\max }$ はほぼ一定かやや増加する が， $\mathrm{M}_{\min }$ の絶対值は繰返しにともなって漸減する傾向を 示し，繰返し終期には急減する。寿命がおよそ $10^{6}$ 回程 度となるような小さな曲げ変位を負荷した場合について 

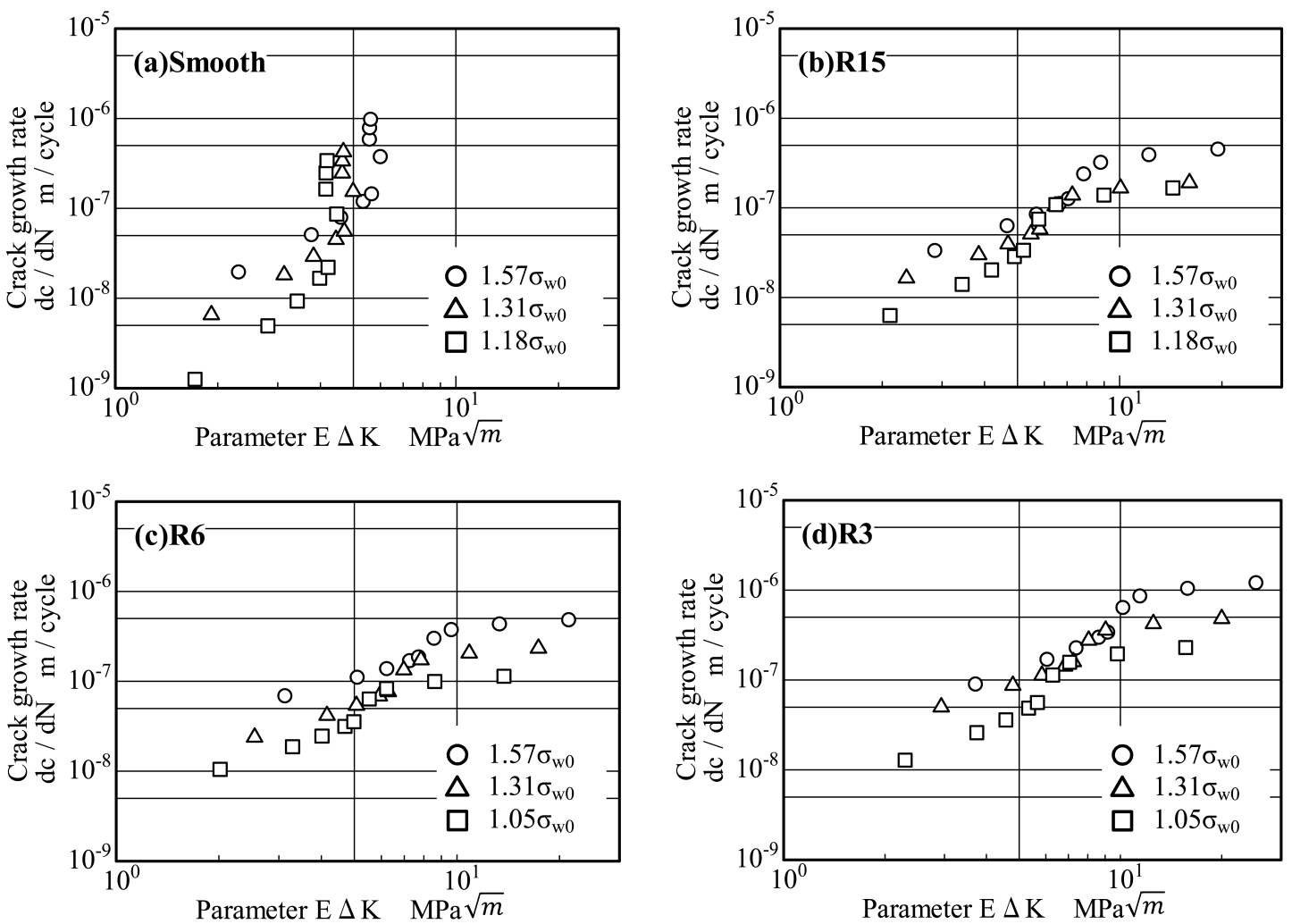

Fig. 11 Crack growth rate dc/dN versus parameter $\mathrm{E} \Delta \mathrm{K}$.

も測定したが，モーメントの変化は Fig. 15 に示すほど 顕著ではないものの，変化傾向は同様であった。

Fig. 16 は，R6 曲げ加工材の加工部内側および外側表 面におけるひずみ測定により得られた繰返し数比 $\mathrm{N} / \mathrm{N}_{\mathrm{f}} \fallingdotseq$ 0.5 の時点でのヒステリシスループの例を示したものであ る. 曲げ加工部を開き, 曲率半径 $\mathrm{R}$ を増す方向に負のモ一 メントが作用する時に内側表面に生じる引張ひずみは， 正のモーメントの場合の圧縮ひずみよりも大きく，かつ 平均引張ひずみを生じている。外側表面では，それほど 顕著ではないが逆に平均圧縮ひずみを生じている。一部 の試験では繰返しを中断して試験片を取外し，表面での 残留ひずみを測定したが，ヒステリシスループから得ら れた值と良く一致した。

以上のように，曲げ加工材では繰返しにともなって加 工部内側には引張りの, 外側には圧縮のひずみが残留し, かつ内側表面から発生した疲労き裂が成長するため，曲 げ加工部を開き，曲率半径 $\mathrm{R}$ を増す方向の変形が容易と なり，しだいに負の曲げモーメントが減少すると考えら れる. Fig. 11〜 13 のき裂成長速度の評価では繰返し曲 げモーメントは一定とみなして応力を計算していること から，き裂の長い領域で曲げ加工材と平滑材の成長速度 が相違するのは，このき裂を開口させる方向のモーメン トの減少を考慮していないことがその一因である。また， 曲げ加工材のき裂先端での応力の評価には便宜的に Newman-Raju の解を用いたが，断面内での曲げの中立軸 は曲率半径 R の減少につれて内側表面方向に移動し，応 力も中立軸について非対称な曲線状の分布となることか

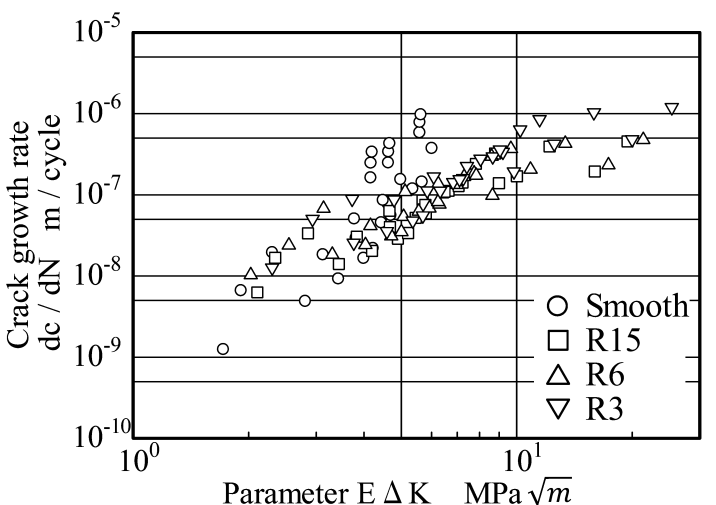

Fig. 12 Summary of dc/dN and $\mathrm{E} \Delta \mathrm{K}$ relation.

ら，正しく評価されているとはいえない。曲げ加工材に おけるき裂成長を簡便に精度よく評価できる方法につい てさらに検討を要する.

本研究では, $\mathrm{R}=3 \mathrm{~mm}$ 以上の曲率半径を有する曲げ 加工材の疲労強度について報告したが，以前，同一材料 のこれ以下の曲率半径となるよう曲げ加工した試験片を 用いて面外曲げ試験を行ったところ，長寿命域での疲労 強度は R3 曲げ加工材よりもやや高くなるという結果が 得られている.3.き裂開口方向の曲げモーメントの減少に よるき裂成長速度の低下に関連したものではないかと推 察されるが，加工部内側表面でのき裂観察が困難である ため現時点では確認していない。また，本研究で得られ た知見が異なる材料や板厚の曲げ加工材に対して適用可 能か否かについて，さらに検討する必要がある。 


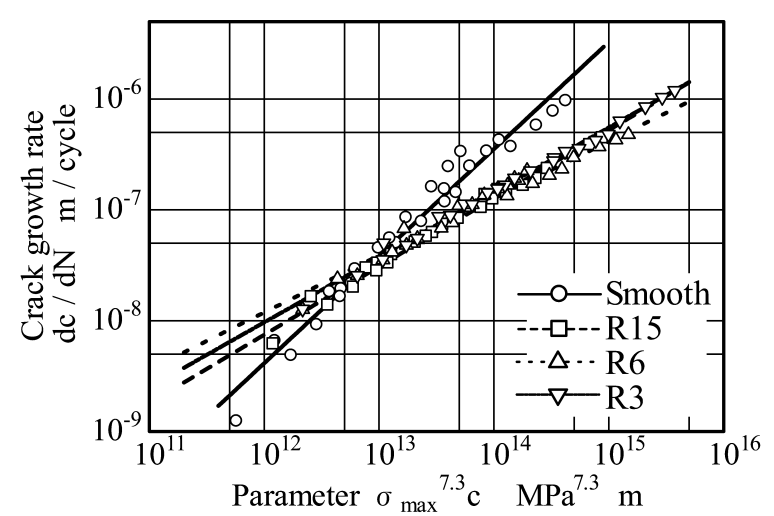

Fig. $13 \mathrm{dc} / \mathrm{dN}$ versus $\sigma_{\max }{ }^{7.3} \mathrm{c}$.

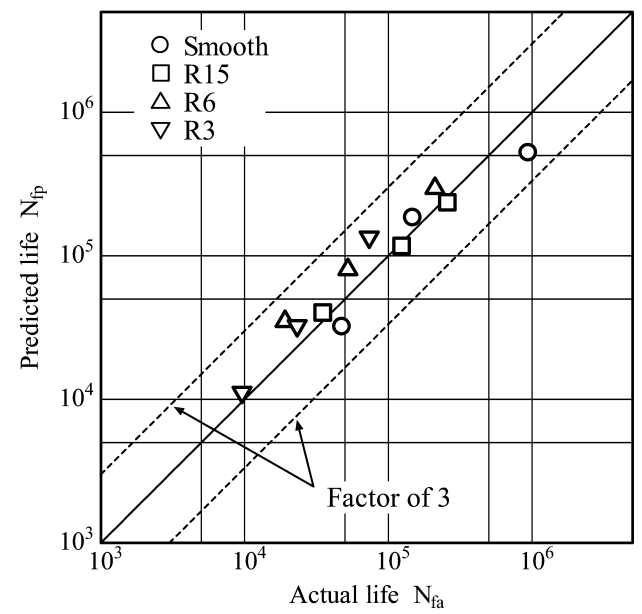

Fig. 14 Comparison of predicted and actual lives.

\section{4 結 論}

曲げ加工が板材の疲労強度に及ぼす影響について明ら かにするため，種々の曲率半径を有するアルミ二ウム合 金の $90^{\circ}$ 曲げ加工板材を用い, 変位制御下で両振り面外 曲げ疲労試験を行なった。

曲げ加工材の度労強度は平板平滑材よりも低下し，曲 率半径が小さくなるほどその減少は著しい。曲げ加工に ともなう応力集中のため, 最大曲げ応力は加工部の内側 表面中央付近に生じ，疲労き裂はこの応力集中部から発 生, 成長した。この曲げ加工部に生じる応力集中のため, 曲率半径が小さくなるほど疲労き裂は早期に発生する。 また平滑材に比べると，とくにき裂長さが短い繰返し初 期段階でのき裂成長が速く，加工部の曲率半径が小さく なるほどき裂成長速度は増大する。

繰返しにともなって曲げ加工部内側には引張りの，外 側には圧縮のひずみが残留し，かつ内側表面においてき 裂が成長するため，曲げ加工部を開き，曲率半径を増す 方向の変形が容易となり，しだいに曲げモーメントは減 少する。このため, 繰返し終期には曲げ応力は低下し, き裂成長速度は平滑材と同程度となる，以上のことから， 板材に曲げ加工を施すと疲労強度が低下するのは，応力 集中のため疲労き裂が早期に発生し，かつ繰返し初期に おけるき裂成長が促進されるためであることが明らかと なった。

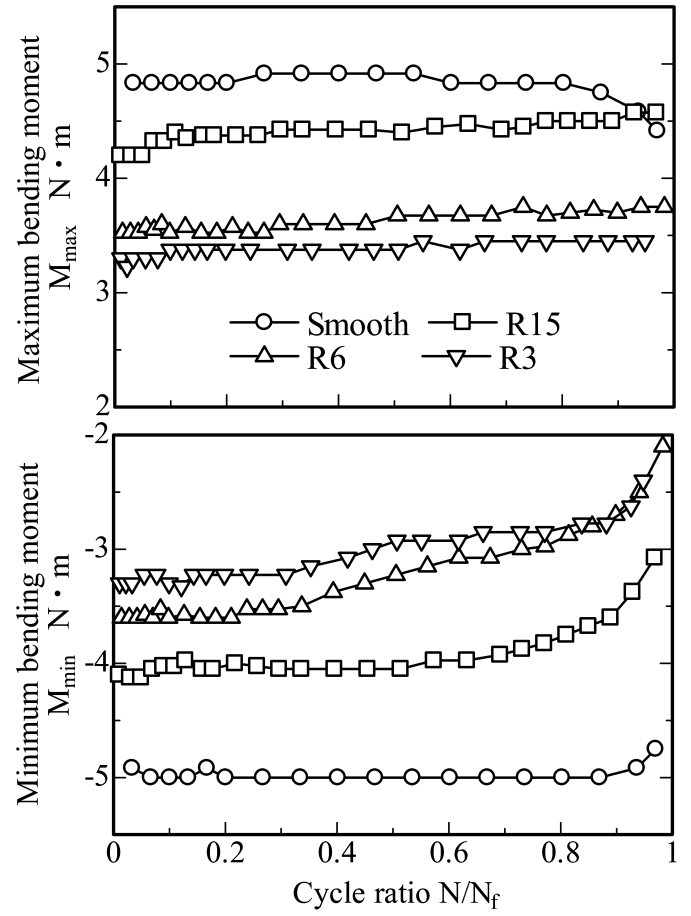

Fig. 15 Variation of bending moment with number of cycles.

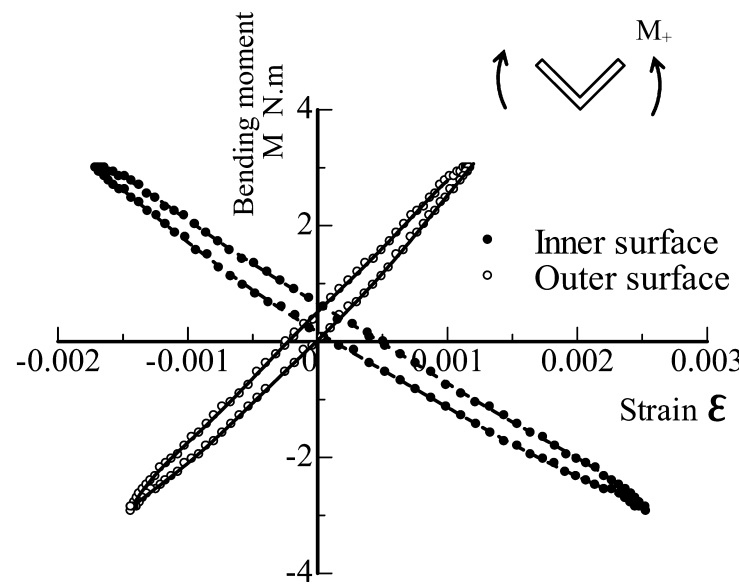

Fig. 16 Hysteresis curves at $\mathrm{N} / \mathrm{N}_{\mathrm{f}} \fallingdotseq 0.5$ in R6 bent specimen.

本研究は, JUKI 株からの委託研究として行われたも のである。関係者各位に謝意を表す。

\section{参 考 文 献}

1) N. Yahata, M. Watanabe and T. Jidaisho, “ Application of fluidic-device type fatigue testing machine (Evaluation of reversed plane-bending fatigue strength of aluminum alloy plates bent to $90^{\circ} \mathrm{V}$-shape)”, Journal of Material Testing Research Association of Japan, Vol.41, No.2, pp.57-61 (1996).

2 ) N. Yahata, M. Watanabe and H. Yamamoto, "Application of fluidic-device type fatigue testing machine (Evaluation of reversed plane-bending fatigue strength of cold rolled steel sheets bent to $90^{\circ}$ V-shape)", Transaction of the Japan Society of Mechanical Engineers, Vol.64, No.628, pp.333-338 (1998).

3) K. Ohkawa, A. Kudo, T. Ando and I. Ohkawa, "Fatigue 
strength and deformation behavior of bent-worked aluminum alloy under plane bending”, Proceedings of the $55^{\text {th }}$ Japan Congress on Materials Research, pp.187-188 (2011).

$4)$ K. Ohkawa, A. Kudo, T. Ando and I. Ohkawa, "Fatigue behavior of bent aluminum alloy under plane bending", Proceedings of the 50th Chugoku-Shikoku Branch JSME annual meeting, CD-ROM, No.125-1, 207 (2012).

5 ) K. Ohkawa, A. Kudo, T. Ando and I. Ohkawa, "Crack growth and fatigue strength of bent aluminum alloy under plane bending”, Proceedings of the 48th Tohoku Branch JSME autumn meeting, pp.114-115 (2012).

6 ) T. Hasegawa, A. Kudo, T. Ando and I. Ohkawa, "Fatigue strength in bent specimens of aluminum alloy under plane bending", Proceedings of the 60th JSMS annual meeting, CD-ROM, 128 (2011).

7 ) R. T. Fenner, "Engineering Elasticity, application of numerical and analytical techniques”, pp.132-140 (1985) ELLIS HORWOOD.

8) A. Moftakhar, A. Buczynski and G. Glinka, "Calculation of elasto-plastic strains and stresses in notches under multiaxial loading”, International Journal of Fracture, Vol.70, pp.357-373 (1995).

9) H. Kitagawa, S. Takahashi, C. M. Suh and S. Miyashita, "Quantitative analysis of fatigue process-microcracks and slip lines under cyclic strains”, ASTM STP 675, pp.420-449 (1979) ASTM, Philadelphia.
10) A. S. Kobayashi and A. N. Enetanya, "Stress intensity factor of a corner crack”, ASTM STP 590, pp.477-495 (1976) ASTM, Philadelphia.

11) K. Tanaka, T. Hoshide and O. Maekawa, "Surface-crack propagation in plane-bending fatigue of smooth specimen of low-carbon steel”, Engineering Fracture Mechanics, Vol.16, No.2, pp.207-220 (1982).

12) J. C. Newman, Jr and I. S. Raju, "Stress-intensity factor equations for cracks in three-dementional finite bodies subjected to tension and bending loads", NASA Technical Memorandum, 85793 (1984) NASA.

13) N. Kawagoishi, H. Nishitani, $X$. Wang, H. Ide and H. Tanaka, "Effect of cross-sectional shape of specimen on fatigue strength under plane bending (Investigation based on small-crack growth law)", Transaction of the Japan Society of Mechanical Engineers, Series A, Vol.62, No.595, pp.607-613 (1996).

14) Division of $X$-Ray Study on Fatigue, "Data sheets on residual stresses and their change due to fatigue”, Journal of the Society of Materials Science, Japan, Vol.25, No.277, pp.10101019 (1976).

15) M. Watanabe, N. Yahata and H. Yamamoto, "Reversed plane-bending fatigue strength of high tensile steels sheet bending to $90^{\circ} \mathrm{V}$-shape”, Proceedings of Society of Automotive Engineers of Japan, No.33-99, pp.5-8 (1999). 